\title{
The Subaltern in Some Selected Poems by Mahmoud Darwish
}

\author{
Tawfiq Yousef \\ Middle East University, Amman, Jordan
}

\author{
Aseel Abu Al-Rub \\ University of Jordan, Amman, Jordan
}

\begin{abstract}
The concept "Subaltern" or the "Other" has been a subject of discussion and debate in many fields such as Marxism, cultural studies, Orientalism, post-colonialism, history, sociology and politics. Consequently, many eminent critics and theorists have approached it from different perspectives. This study, depending on the post-colonial theories of many critics such as Edward Said, Gayatri Spivak and others, explores the type of voice given to the subaltern in some selected poems by Mahmoud Darwish. For Darwish, the subaltern can and should speak.
\end{abstract}

Keywords: subaltern, postcolonial, Darwish, identity

There have been many broad tags which identify "subaltern" as the oppressed, colonized, or simply the Third-World people. In his article, "A Brief History of Subalternity" (2001), David Ludden traces the terminological development of the term "subaltern" from a historical perspective and concludes that the deep roots of this term go back to

the late medieval English as it applied to vassals and peasants. By 1700, it denoted lower ranks in the military, suggesting peasant origins. By 1800, authors writing 'from a subaltern perspective' published novels and histories about military campaigns in India and America. (p. 3)

In the 1920s and 1930s, the term subaltern was used in a nonmilitary sense by the Italian Marxist Antonio Gramsci (1891-1937). Gramsci employed this term to refer to the groups of people who are outside the established structure of political representation. According to the Gramscian use of the term subaltern, it includes slaves, peasants, religious groups, women, and different races that constitute the minority of the Italian society and who are on the margin of history.

By the end of the 1970s, Gramscian thoughts became widely spread and influential in the English-reading world after translations of Gramsci’s The Modern Prince (1957) and Prison Notebooks (1966) had appeared. Inspired by the Gramscian concept of subaltern, a group of Indian and English historians and critics collaborated with each other and published three volumes of essays called Subaltern Studies: Writings on South Asian History and Society (1982-1987). These essays deal mainly with subaltern themes stimulating from issues related to the Indian society. By the beginning of 1990s, this group became internationally acknowledged and known as Subaltern Studies Group (SSG). The Subaltern Studies Group includes many outstanding critics all over the world such as Ranajit Guha (b. 1923), Gayatri Chakravorty Spivak (b. 1942) and Partha Chatterjee (b. 1947).

Gayatri Chakravorty Spivak is an Indian theorist and philosopher who combines the notions of deconstruction, feminism, Marxism, post-colonialism, and subaltern studies in her essays and lectures. Spivak

Tawfiq Yousef, Ph. D., English Department, Middle East University.

Aseel Abu Al-Rub, M.A. Graduate, English Department, University of Jordan.

Correspondence concerning this article should be addressed to Dr. Tawfiq Yousef, English Department Amman, University of Jordan, Amman, Jordan. 
raises many issues related to the colonizing powers and the subaltern groups. She believes that colonization lies at the heart of the British history and culture. However, the study of the British history, culture, and literature does not show much importance to the focal role of these colonized groups in the establishment of the British history and literature. Instead, these groups are suppressed and neglected along with their historic, cultural and literary output. Spivak believes that "to study the role of imperialism in the literature of colonizing countries can help make visible the worlding of the so-called Third World” (Parker, p. 255). By this, she hints at engaging the subaltern groups and their literary output in the central process of producing the British literature, rather than treating them as if they were on the margins of its literature. Spivak believes that it is not enough to think of the "the Third World writing as a separate thing out on the margins of metropolitan culture. Instead, given the hybridity or interconnectedness of cultures, the Third World is part of the metropolitan world” (Ibid., p. 255).

Spivak's efforts reached their peak of triumph with the publication of her widely spread and highly theoretical essay "Can the Subaltern Speak?” (1988). In this essay, Spivak is remarkably influenced by Gramsci's conception of the "subaltern". Spivak chooses her own model of subaltern group, which is the Indian women, and she views her ideas by discussing the issue of "sati," which refers back to a traditional Hindu practice of widow burning during the time of the British colonizing rule in India. Spivak finds the question whether the subaltern (the Indian woman) can speak freely for herself and for other Indian women as an irresolvable and problematic question because, according to Spivak, "there is no true voice, no essence, of African American women, or Indian women or any subaltern group (or any group at all) and that whether we say there is, we demeaningly oversimplify and essentialise Indian women” (Ibid., p. 268). Thus, Spivak asserts the difficulty for any subaltern group to speak for themselves as each group has different opinions about the same issue, and so different voices will be raised in the same subaltern group. In addition, because of the multiple opinions and the dissimilar voices of any subaltern group regarding a particular issue, Spivak illustrates that it is even harder for anyone outside the subaltern group to find out how this group really thinks or to hear their real voice.

A new approach that provokes a storm of interest and has had a profound influence on postcolonial theory is Orientalism. Motivated by his commitment to the Palestinian cause and influenced by Nietzsche, Edward Said (1935-2003) developed and exposed his own version of postcolonial theory by linking the postcolonial theory and its principles with the real, social and political struggle in many countries in our modern time. Said defines Orientalism as "the generic term that I have been employing to describe the Western approach to the Orient; Orientalism is the discipline by which the Orient was (and is) approached systematically, as a topic of learning, discovery, and practice" (Orientalism, p. 73). Said argues that "the West has constructed a colonial discourse that produces the ideas about the Orient” (Parker, p. 248). He calls this colonial discourse Orientalism and uses the term "Orient" to refer to the Islamic Middle East. In addition, Said calls for a critical decentered consciousness that refutes the Western attitudes toward the Middle East which are based on false assumptions and prejudice against Arab-Islamic countries and peoples.

The theme of subaltern is represented in Said's works to refer generally to colonized oppressed people. However, on certain occasions, this term is used by Said to specifically refer to the Palestinian people. Said has been considered as the outspoken advocate for Palestinian issues and he tries in many of his works to present the Palestinian-Israeli conflict from an Eastern point of view. In one of his early political essays, "The Palestinian Experience" (1968-1969), reprinted in The Edward Said Raeder (2000), Said calls for the right of 
the Palestinian people to have their own identity, culture, history, and politics far away from the Israeli domination. In this essay, Said also describes in detail the situation of the Palestinians who remained in Palestine after the war of 1948 and those who left it and lived as refugees in camps in some Arab countries such as Jordan, Iraq, Lebanon, and Syria. He provides historical and political events identifying crucial moments preceding and following the two wars of 1948 and 1967. He writes, for example, about the political silence the Palestinian people witnessed after the war of 1948:

Since 1948, the Arab Palestinian has had to endure a political living death, and whatever he now experiences in the way of vitality is because since 1967 he has begun to revitalize his thought just to avoid total extinction, and because the dreams of Arabism have broken on his acutely exposed situation. The two reasons are different sides of the same coin. The main characteristics of the Arab Palestinian's life since 1948 had been his peripherality, his isolation, and his silence—all of those are conditions of displacement and loss. (Said, 2000, p. 32)

While discussing the term subaltern from different postcolonial perspectives, it is of great interest to indicate how critics from outside this field perceive subaltern and other related postcolonial issues. Indeed, just as the Western military and political powers have dominated and mapped the policies of the other parts of the world, the Western culture and thought have also controlled the world's way of thinking and preserving the different subjects by highly evaluating the Western traditions, culture, literature, and thought, disregarding any others and considering them as marginalized and neglected.

Focusing on the cultural and historical aspects, it is clear that Said agrees with many critics such as Gramsci that the Occident uses its colonizing powers to have domination on the rest of the world by highly evaluating the Western culture, history and literature, considering the Western ways of thinking as universal and its literary and cultural products as canonic, ignoring and marginalizing other cultures' literary products. Said's main thesis was that the Western image of the East was heavily biased by colonialist attitudes which represented the East as the other, the opposite of what the West stood for: rationality, civilization, modernity, progress, intelligence, activity, morality, etc. Said called for a new conception of the Orient to redress the balance in the East-West dichotomy. Eventually, Said became admired for his courageous defence of the Palestinians and their rights.

In this respect, Mahmoud Darwish (1942-2008) gives an outstanding epitome. He is considered as a subaltern because he is a Palestinian Arab poet who suffered from "double jeopardy". As an Arab who belongs to the Middle East, he is oppressed by Western culture and its attitude about the East, and as a Palestinian citizen he is oppressed by the Israeli occupation. Nevertheless, Darwish has been able to speak for himself and his own people in his real life and in his literary works as he was a political activist and a national poet and most of his political notions are reflected in his poems. Darwish, as a representative of the Palestinian subalterns, addresses many notions in his poems such as identity, resistance, freedom, hope, death, martyrdom, exile, and other relevant topics that are closely connected to the subaltern concept. His voice is heard locally and globally to prove to everyone that the subalterns can understand their situation and are able to speak for themselves and defend themselves as well.

What makes the Palestinian issue remarkably intricate is the fact that the Zionist leaders believe that the creation of Israel requires necessarily the destruction of Palestine and the displacement of its people. In his book, The Arab-Israeli Conflict (1964), Fayez A. Sayegh asserts this viewpoint as he defines the Palestinian-Israeli conflict as "an instance of dispossession: not one individual dispossessing another, but a whole multitude dispossessing an entire people from its ancestral home” (p. 2). In point of fact, this national 
tragedy created a new generation of writers whose main concerns are to protect their land, return to their homes, assert their Arab Palestinian identity, and debunk the Israeli false claims. In her book, Resistance Literature (1987), Barbara Harlow (b. 1948) reinforces the importance of poetry as a weapon in the hands of the Palestinian poets in their political struggle against the Israeli enemy. She asserts that "poetic language is not envisaged here as a rarified or transcendent means of expression, detached from the political reality of struggle, but rather it is considered as an integral part of the ideological foundations of the new social order” (p. 62).

Harlow's Resistance Literature discusses the literature of colonized peoples in Africa, Latin America, and the Middle East. She notes that such works are considered as resistance literature because they are connected with armed struggle in these countries and the main themes of these works revolve around identity and nationalism. In addition, Harlow gives a comprehensive definition of the concept of "Literature of Resistance." She defines it as "a particular category of literature that emerged significantly as part of the organized national liberation struggles and resistance movements in Africa, Latin America, and the Middle East” (p. 17). Overtly, this definition indicates that the writers participate in the struggle in their countries with their literary works alongside the fighters who use their guns. She goes on to assert that "the role of poetry in liberation struggle itself has thus been a crucial one, both as a force for mobilizing a collective response to occupation and domination and as a repository for population memory and consciousness" (Ibid., 34). Harlow indicates that the concept "resistance" was first applied to the Palestinian literature by the Palestinian critic and novelist, Ghassan Kanafani in his study Literature of Resistance in Occupied Palestine: 1948-1966 (1968).

After the 1967 War, new themes were ascribed to this type of poetry which is called by some critics "the Israeli-Arab poetry" or "political poetry". In describing this newly-developed type of poetry Emile Nakkleh indicates in his article, "Wells of Bitterness: A Survey of Israeli-Arab Political Poetry":

Israeli-Arab poetry graphically depicts the discrimination against, and mistreatment of, the Arab minority in Israel. Unlike refugee poetry bemoaning an idealized lost heritage, Israeli-Arab poetry realistically portrays the bitterness, despair, and tremendous surge toward freedom and rebellion on the part of the Arab minority. (p. 245)

Therefore, the political poetry came as a reaction to the discrimination and suppression exercised by the Israeli colonization of the Palestinian people in Palestine. It celebrates such themes as valor, chivalry, self-assertion and self-sacrifice. In his book, Critical Perspective on Modern Arabic Literature (1980), Issa J. Boullata points out that,

as a reaction to the discrimination and suppression by the military governments in the fifties, the political poetry of the sixties has come to be called the poetry of resistance. It has portrayed the bitterness of this treatment with vigor and daring, even rebelliousness. Moreover, the political poetry is a truly creative outpouring of spirit. (p. 248)

Mahmoud Darwish was one of the main literary pillars who, with his many great poems, contributed a great deal to the Palestinian poetry. His poetry is perceived by most of the critics as sensitive, influential, rebellious, and patriotic. In his poems, Darwish writes from the perspective of the Palestinian people, who are considered as subaltern groups and Darwish tried his best to represent these voiceless and oppressed groups despite the various differences among them. As a prolific poet, Darwish's poems depict many types of subalterns which cannot be all discussed in this paper. It is of great importance to narrow the scale of the discussion in order to give an adequate and feasible conception of Darwish's perception of the "subaltern." Thus, this study focuses on four circles or zones of subalterns: the poet's self, the family, the country, and the nation. 


\section{The Poet's Self}

Darwish, with his personal experiences, represents the state of the Palestinians in the second half of the twentieth century in exile out and under the Israeli siege in Palestine. In their book, Mahmoud Darwish: Exile's Poet (2008), Hala Khamis Nassar and Najat Rahman comment on Darwish's childhood and its role in forming his later perspectives about life, "not surprisingly, given this personal history, the poetry of Darwish is preoccupied with displacement-a literal displacement, coterminous with the Nakba's rupture of history and the other losses that follow, and also the displacement of the self from itself” (pp. 1-2). Darwish's poetry is focused on the experiences of exile and displacement in an effort to regain an identity and a nation. Eventually, Darwish became the poet of the Palestinian cause and identity par excellence, a poet associated with the suffering and the hopes of the Palestinian people.

Darwish's personal experience and its connection to so many of his people's experiences have established him as a national poet and a spokesman for his people. In one of his poems, "Cactus Forever," Darwish recounts the memories of his departure from Palestine to Lebanon. This story represents many Palestinian people as they have similar memories of similar experiences:

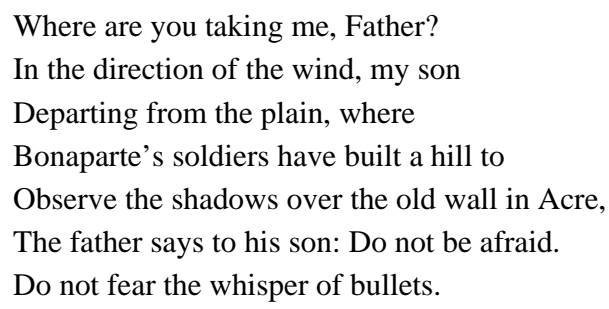

Why Have You Left the Horse Alone? (1995). Translated by Nezar Andary

This autobiographical poem reflects the experience of exile, narrating the story of a Palestinian father and his son, escaping from Palestine to Lebanon due to the Israeli assault of Palestine in 1948. As they leave, the father tells his son to remember his land and the ruthless enemy who has taken his ancestors' land and killed his family. In his essay, "Subaltern Voices and Perspectives: The Poetry of Mahmoud Darwish,” Balraj Dhillon examines this poem, arguing that Darwish, as a poet of resistance, uses memories in his poetry as an alternative to the historical discourses adopted by the imperial hegemonies. Dhillon illustrates that "this type of memory speaks to the voicelessness of the oppressed; however, the poem gives them that voice. Darwish is attempting to write his own story to safeguard his inheritance-an inheritance that will not dispossess him” (p. 52). Thus, this poem raises the issue of memory as a means of resistance. It is obvious that Darwish employs the memories as a tool in the hand of the Palestinian subaltern to resist the fake discourses and propaganda exposed by the Israeli colonizers.

Generally speaking, memory in Darwish's poetry is a journey into personal as well as collective experience. Later in his life, Darwish wrote his famous work Memory for Forgetfulness (1982), a sequence of 
prose poems in which he recorded his extended reflections on the siege of Beirut and his conception of such correlated words as writing, exile, homeland and resistance. In addition, Darwish used this occasion to reflect on the loss of the Palestinians' homeland.

\section{The Family}

Darwish, as a representative of the Palestinian subalterns, speaks about himself in a way that everyone can find lines in his poems that assimilate with them and with their memories. Thus, Darwish's poetry is full of autobiographical details that are part of Darwish's memories, which simultaneously, represent the other Palestinians in Palestine or in Exile. However, the figures of family Darwish uses have, in addition to their literal meanings, figurative meanings that connect them with the Palestinian history, heritage religion, and politics. This can be clearly seen in Darwish's poem “For My Mother” when he says:

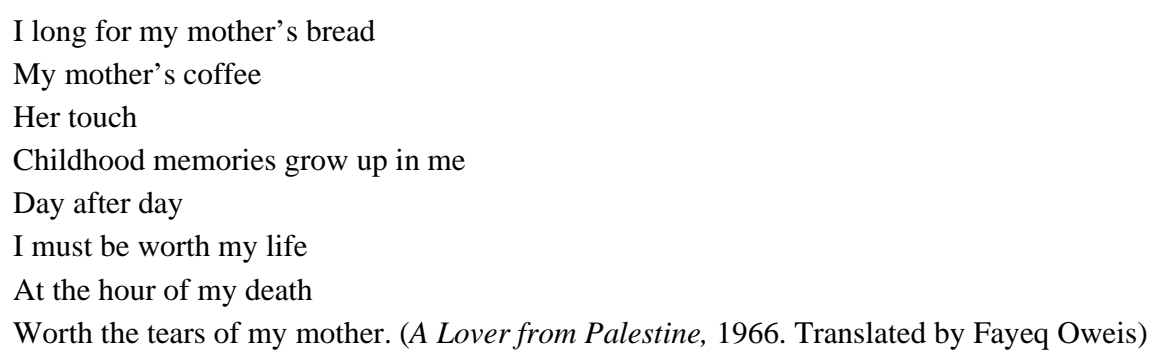

These stunning lines seamlessly blend the childhood memories, love of the homeland, and hope in bringing it back in the future. The persona's longing for his childhood memories is the basic motivation for his desire to go back to his mother as he wants to restore these memories and relive them again. Though this poem has a seemingly simple structure, it contains many metaphors and references that genuinely express the Palestinian refugees' consciousness and deep feelings. For example, the figure of mother here could refer to the persona's real mother or may be it symbolizes his homeland. In both cases, the poem opens with the persona expressing his yearning for his childhood memories such as his mother's bread, her coffee, and her touch. These feelings wake up his desires of returning back to his mother/home. Thus, the poem continues with the persona asking his mother to strongly bind him with a lock of her hair and to cover his bones with his country's grass if he returns one day to his country. In addition, the poem reflects how the persona has hope and strong belief in the future when all the Palestinian refugees and the speaker will return and settle in their homeland. In this poem, Darwish symbolically connects both the theme of motherhood and nationalism together, because, according to him, the land is connected with the purest and most sacred feelings anyone may have. Thus, he connects the land with the love for the mother and childhood dreams.

During the 1970s, many other poets shared Darwish a positive view because now the Palestinian people had overcome the political shock they encountered in the 1967 and they started to recognize what was going on, trying to diagnose the main reasons of the catastrophic situation they had. Among such poets are Samih Al-Qasim and Tawfiq Ziyyad. Darwish, together with many other fellow poets, has developed various new poetic themes and techniques which they employed in their literary works. Bennani describes Darwish's literary growth as a result of the accelerated political events in Palestine during the 1960s and asserts that during this period Darwish "emerges as an innovative craftsman, knowledgeable of and sensitive to not only Arabic poetry but also the poetry of other nations, with a penchant for symbol and myth” (p. 18). For instance, 
in his poem "My Father," Darwish gives a passionate image of a father, advising his son to never leave his country. In this poem, Darwish relies on the Greek myths as he portrays the Palestinian refugee father as being a strong fighter similar to Odysseus, the Greek hero who was able to return back to his homeland after meeting the most intricate challenges with his determination and might:

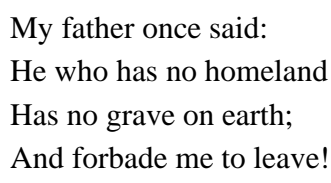

Qtd. in Harlow, (p. 71).

In the above short poem we learn about the story of an exiled man who is advising his son never to leave his homeland because he will never find a grave in the earth to be buried in. If he leaves, he will perish in exile as foretold by the father. The father's gloomy vision of exilic experience forebodes the doomed destiny of the disobedient son if he does not heed his father's advice and leaves his birthplace and homeland. Here, we witness a close tie between the body and the earth, identity and the land. The son's very being is an extension of the land to which he belongs. His identification with it becomes the bond that gives continuity to his existence. This vision reflects the change of the Palestinians from peasants with a homeland into refugees in exile without a homeland.

Both of the Palestinian father and Odysseus show steadfastness and determination by holding on to their homeland and never giving a chance to the invaders who want to have control over it. Harlow sees "in the departure of Yasser Arafat and the Palestinian fedayeen from Beirut, following the 1982, Israeli invasion of Lebanon and the summer-long siege of that city, the image of Odysseus," who leaves after the Trojan war to go on a long journey of moving from one city to another (p. 71). This viewpoint gives a further political dimension to the use of the Greek myth in this poem as the myth of Odysseus can stand not only for the image of the Palestinian father who warns his children and advises them to never leave their country, but also it stands for the late Palestinian President Yasser Arafat (generally considered the father of all the Palestinians), who tried his best to protect the Palestinians and return their land and rights. In his article, "Alternative History, Expanding Identity: Myths Reconsidered in Mahmoud Darwish’s Poetry,” Ipek Azime Celik comments on how Darwish uses myth in his poems to show the Palestinian identity and write its history by giving an alternative historical discourse that opposes the historical discourse structured by the Western and Israeli hegemonies. In Celik's words: "His Darwish poetry delves into the politics of narrating history and sustaining myths, in order to reveal the complexities and contingencies history writing and mythmaking bear for formulating Palestinian national identity” (p. 273).

Another poem which addresses the themes of family, exile, alienation, homelessness and familial oppression is "Oh my father, I am Yusuf” cited below:

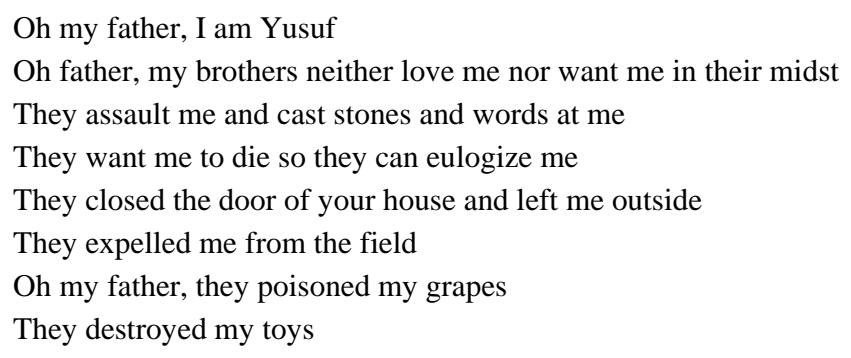




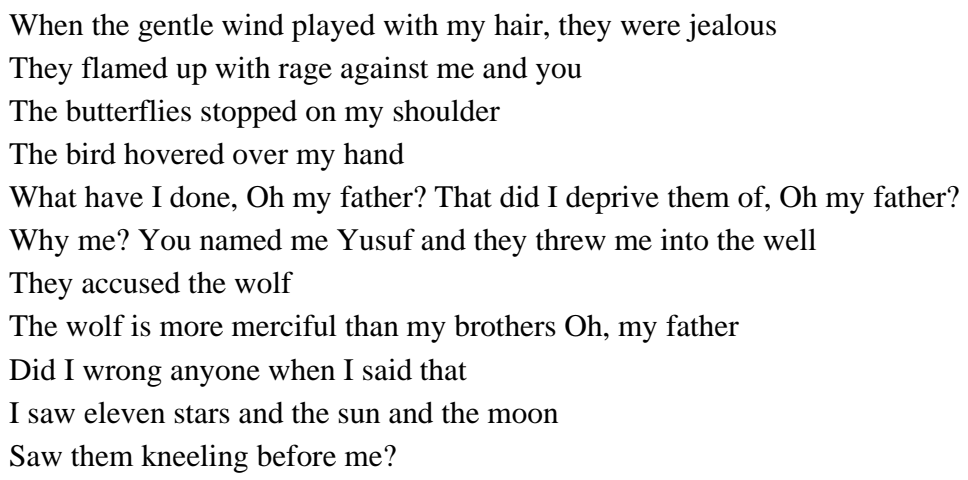

Fewer Roses, 1985. Qtd. in Raheb, (p. 97).

The poem shows the feelings of a Palestinian who finds himself away from his homeland and furthermore the victim of discrimination and oppression even by the people with whom he is supposed to have, at least theoretically, close ties of blood and ethnic relationships. Drawing upon the Qur'anic story of Yusuf and his brothers, Darwish depicts the relationship of hatred and discrimination between the Palestinians and the Israelis as being similar to that between Yusuf and his brothers who were invariably jealous of him and consequently conspired to kill him in a wicked and deceitful manner by throwing him in a well and pretending that he was killed by the wolf while he was away from them.

In the same poem, Darwish is addressing his father as the head of the family and household. Rendered in modern terms, the story symbolizes the relationship between the Palestinians and the Israelis. Although they derive from the same lineage (Abraham) and so are supposed to be brothers, they are divided by their feelings of deep hatred, animosity, jealousy, racial and ethnic discrimination. In his article, "Home, Homeliness and Search for Identity in Mahmoud Darwish’s Poetry,” Rashad Al Areqi maintains that,

the words used by the poet indicate the deliberate action that causes the suffering of Palestinians; they [the Jews] make them live strangers outside of their country and strangers inside their country as well. Darwish portrays the weakness of Palestine by brining to our attention the innocence of a boy who is playing with his toys and the colonizers tend to destroy his field, his vineyard, and his toys. (p. 34)

The Jews do not want to see the Palestinians in their home and so they want to see them in exile and away from their homeland. As a family, Palestinians and Jews are self-divided and torn by deep conflict and racial discrimination. Palestinians are forced to live as strangers whether in their homeland and outside. They are alienated and deprived of their ethnic origins as well as their human rights. In postcolonial terms, they are the subalterns who are trying to resist oppression and suppression against the colonizers.

\section{The Country}

Many of Darwish's poems celebrate the Palestinian identity and land and sound the alarm to Palestinian people, urging them to fight bravely for their home and rights and to firmly hold on to their land and never leave it. This can be clearly seen through a critical reading of Darwish's poem "Beirut," where Darwish retells his memories of the Israeli invasion of Lebanon in 1982 and the sequences of such historical event on the Arabs, particularly the Palestinians:

We could not find a thing to show our identity

Except our blood in stains upon the wall 
We softly sang

Beirut our tent,

Beirut our star.

As the title suggests, this poem describes the situation in Beirut during the Israeli siege, which was launched in 1982, with the intention of destroying the Palestinian Liberation Organization there. The poem gives a deep insight into the daily life of the Palestinian refugees and the subsequences of this aggressive invasion. Darwish in this poem does not offer a political or historical discourse of these devastating events; yet, he provides a postcolonial perspective, showing the subaltern Palestinian refugees living under tough conditions caused by the same Israeli enemy. In the same poem Darwish writes:

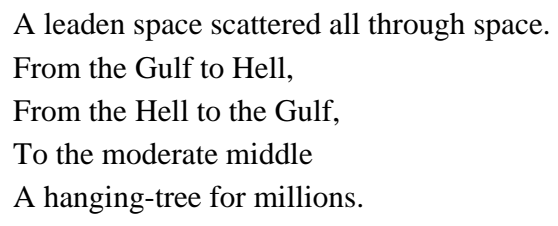

Ibid. (p. 51)

Here Darwish refers to the war which is like the trap or the gibbet that does not escape millions of the Palestinian and Lebanese people because the civil wars do not usually discriminate between kind or evil people, Muslims or Christians, Palestinians or Lebanese. Again, in this poem, the issue of memory as a form of resistance exposes its importance and deep effect. Darwish's memories of his land, identity, religion, and the Palestinian culture make them serve as a tool to give a voice to the silenced subalterns and to resist all the colonial, historical, and political discourses that aim to distort the genuine Palestinian culture and history.

In the above mentioned poem, Darwish further shows his masterful skills in drawing the readers' attention to his ideas and feelings, especially because this poem depicts a crucial stage in the life of many Palestinians in exile. Though Darwish spotlights the mindset of the person who is a Palestinian refugee living under siege in Lebanon, the poem gives hints to rays of hope in the future:

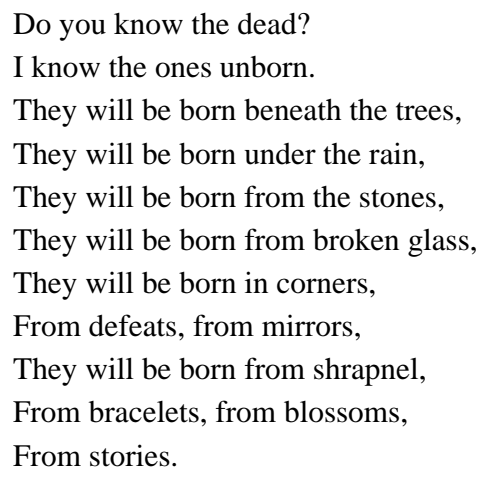

These few lines reflect Darwis's hope in the future generations to change the sad and desperate present into a bright and optimistic future. In his article, "Mahmoud Darwish’s Love Poem: History, Exile, and the Epic Call," Subhi Hadidi indicates this feature in Darwish’s poetry as he believes that “ the voice of Darwish 
seems clear even when obscure, optimistic even when pessimistic, and alluding to the collective even when openly proclaiming itself as that of the individual” (p. 96).

In another poem in his collection The End of the Night (1967), Darwish reinforces the sufferings of the Palestinian intellectuals and their determination to defend their country and the rights of their countrymen:

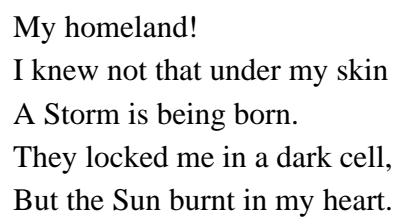

Qtd. in Boullata. (p. 253)

This poem depicts the situation of the prisoners who, in most cases, have been intellectuals and politicians imprisoned inside their occupied homeland. These intellectuals refused to leave their land and stayed in it in spite of all the types of torture, suppression and discrimination. In this poem, Darwish presents some glimpses of the life of the Palestinian intellectuals in Palestine. They suffer from different types of torture and are prevented from free movement. Nevertheless, they appear in Darwish's poem as brave and full of determination, addressing the enemy with a challenging tone because they are determined to express their opinion and speak about their issues and rights. In this poem, Darwish relies heavily on symbols to express his own emotions. Thus, the storm symbolizes the desire for resistance, and the sun symbolizes the hope and the rebellion that will eventually lead the Palestinians to free their homeland and regain their rights.

Darwish, as a Palestinian intellectual, has been able to express his own feelings and to communicate the anguish and painful suffering of his people in his poems. This perspective has been adopted by many critics who have studied and analyzed his poems. This perspective, however, is in sharp contrast with Spivak's viewpoint as she argues that "elite native men may have found a way to 'speak,' but, she suggests, for those further down the hierarchy, self-presentation was not a possibility” (Loomba, p. 234). Darwish’s case provides a totally different situation. Although he is an intellectual and is considered to be amongst the Palestinian elite, he has suffered from the same pressures and oppression Israeli colonizers have practiced on other Palestinian people from different ranks and spectrums of the Palestinian society. Accordingly, he, as intellectual, has suffered the same experiences shared by the other Palestinian people. Darwish in his poems does not only sympathize with his countrymen, but he communicates the shared suffering and pains of all Palestinians, articulating his honest feelings and presenting believable daily situations and accounts, and down-to-earth experiences. Jayyusi seems to adopt this viewpoint in many of her essays. For example, in her essay, "Mahmoud Darwish's Mission and Place in Arab Literary History" (2008), she underscores the role Darwish has played as a Palestinian intellectual by indicating that "Mahmoud Darwish is the poet of the Palestinian identity par excellence. I am speaking here both of the personal identity of the poet and the collective identity of all Palestinians” (2008, p. 8).

\section{The Nation}

Arabism and collective Arab identity have been recurrent themes in Darwish's poems, especially the ones written in the 1960s and 1970s. In such poems, Darwish highlights the importance of the Arab identity and his deep pride of it as appears in his well-known and powerful poem "Identity Card:" 


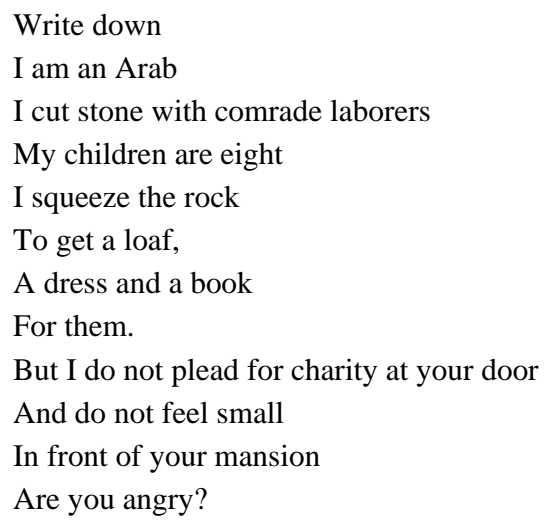

Leaves of Olives, 1964. Translated by Hijjawi.

These lines show clearly how the persona, who is a Palestinian, is proud of being an Arab with Arab history and glory, addressing the enemy with a very angry tone and challenging the Zionist strategies that the enemy employs to deprive the Palestinian people of their land and identity. Darwish here gives an account of the daily hardships a Palestinian father encounters to secure the bread, the clothes and books for his children. However, despite all these difficulties, he will never submit to the Israeli colonizer or ask him for help. Darwish expresses the pride and the steadfastness of the Palestinian people, using a dramatic monologue with simple, direct and convincing language.

Undoubtedly, Arabism and Arab identity have become perhaps the most cherished notion and the core theme in Darwish's works around which other themes revolve. Jayyusi asserts in her essay, "Mahmoud Darwish's Mission and Place in Arab Literary History" (2008), that "the Palestinian might suffer and die alone, but his personal tragedy is linked to the tragedy of the whole” (p. 8). Thus, while expressing his personal experiences and suffering, Darwish has communicated the tragedy and the agony of a whole nation. In his Innovation in Palestinian Literature (2000), Abdul-Fattah Jabr highlights the theme of Arab identity in Darwish's poetry. He asserts that Darwish is proud of being an Arab, refusing to have other citizenship than the Palestinian one and believing that the united Arab culture can be a method of salvation:

I am so far unable to be half a citizen! . . . It seems that our real and imaginary deliverance is a cultural one. . . By the way, the wealth of the Palestinian culture stems from its being not indistinct in the narrow Palestinian geography. Rather, it is widespread in the Arab World and the entire world. (p. 23)

Darwish here hints at an across-the-board project that keeps the identity of each Arab country as well as the unity and coherence of the identity and culture of the Arab nation as a whole, which eventually will lead to an Arab identity based on shared culture, history, language, and religion. This steady Arab identity can stand against any type of colonial plans or political conditions that may negatively affect the Arab world and its peoples. By the way, Edward Said gives a similar view that could lead to salvation. Said suggests a national projects called "Palestinianism" which he imagines as "a political movement that is being built out of a reassertion of Palestine's multiracial and multireligious history. The aim of Palestinianism is the full integration of the Arab Palestinians with lands and, more importantly, with political processes” (2000, p. 16). Thus, both Darwish and Said believe that if the Palestinian people unite culturally, politically, and religiously, they will be able to resist all the colonizing strategies and, eventually, they can return their land and regain their usurped rights. 
In almost all his poems, Darwish shows his political commitment to his people's issues. Even the pomes in which he portrays the daily human events show the deep agony that Palestinian people tragically live in. In her article, "Mahmoud Darwish's Mission and Place in Arab Literary History," Jayyusi asserts that this commitment "applies equally to the poetry dealing with his private experiences, which has as its resource the deep will of Palestinian tragic experience” (p. 9).

By and large, these are the major subaltern Palestinian groups and themes that have been depicted by Darwish. Such poems have always been vivid documents full of the personae's pride for being Arab, full of love for their homeland, and full of faith and hope that the Palestinians will keep on resisting till they free their land and return back to it.

\section{Conclusion}

Gramsci asserts that the subaltern groups are numerous due to their different ideologies, their active or passive affiliations to the dominant political formations, and their attempts to influence the structure of society. Consequently, the history of the subaltern groups is complex and multifarious. Gramsci thinks that the different parties of the subaltern groups have different historical background and fragmented experiences which should be united and developed to be ready and able to participate in forming the fabric of the state's history despite the attempts of the dominant groups to exclude the subaltern groups and reduce their role in the process of making history in the society. Gayatri Spivak’s viewpoints go in harmony with Gramsci’s as she asserts that the only case where subaltern can speak is when the elite express their opinions. According to her, however, such expression does not represent the true voice of the subaltern groups who are mainly the suppressed poor people and women. In his book, After the Last Sky: Palestinian Lives (1986), Edward Said expresses attitudes and views similar to those of Spivak. In his analysis, Said focuses mainly on the Palestinian subaltern groups and he thinks that the subaltern people cannot be easily represented because he thinks that,

no single Palestinian can be said to feel what most other Palestinians feel: Ours has been too various and scattered a fate for that sort of correspondence. But there is no doubt that we do in fact form a community, if at heart a community built on suffering and exile. (p. 5).

Darwish, however, gives a distinctive model about Arab Palestinian writers. Like other Palestinian intellectuals and writers, Darwish has played an important role in changing the political trends and the social events of his nation as he has been able to understand the political and social problems in Palestine and as he tried to spread political and national awareness among all the Palestinian and Arab people. Thus, he has contributed to the re-writing of the Palestinian history by documenting the most important historical and political events from the perspective of the Palestinian subalterns. Darwish uses symbolism, myths, vivid imagery, and simple language to address many issues in his poems such as identity, resistance, freedom, hope, Arabism, martyrdom, exile, and other relevant topics that are closely connected to the subaltern issues.

Darwish attempts to underscore the issue of the subaltern that has been reinforced by his writing both in Hebrew and Arabic so as to reach a wider audience. In addition, his poems have been translated into more than thirty languages including English, French, Russian, Hebrew, German, Spanish, Dutch, and many other languages. Thus, despite being a subaltern poet, Darwish writes in a creative and genuine way that helps him use his personal experiences to reveal not only the suffering of the Palestinian intellectuals, but also the collective consciousness of his people and even the human universality in some of his poems. As Shaheen 
asserts: "Darwish began by writing poems about Palestine, and, after long explorations of obscurity, has arrived at a human poetic enterprise” (p. xi). From the very beginning, Darwish understood the formula of power and the colonized-colonizer relationship and he tried to modify it. In Innovation in Palestinian Literature, Abdul-Fattah Jabr cites a statement by Darwish where he refuses the Western perspective that only the strong nations can write their history and preserve their cultures and traditions:

I refuse to be a loser. By the same token, I hate to be a victim. . . More importantly, I wanted to say that the weak and the losers can write their history, too. That only the strong can write history is a sheer fallacy. They can write it in an official manner, but at the textual level, it is the victims who write their history. This is prejudice to the victim and its right to write its own history. (pp. 18-19)

Thus, Darwish's voice is, consequently, heard locally and globally to prove to everyone that the subalterns can understand their situation and are able to speak for themselves and defend themselves whatever the social or economic rank they belong to. Darwish has been able to express the sorrows and the calamities as well as the memories and wishes of all classes of the Palestinian society in his poems. In fact, the bulk of the poet's oeuvre is dedicated to the depiction of the suffering of the Palestinian subaltern.

\section{References}

Al Areqi, R. (2014). Home, homeliness and search for identity in Mahmoud Darwish’s Poetry. International Journal of English Language Teaching, 1(1), 32-41. Sciedu Press. Retrieved from https://owl.english.purdue.edu/owl/ resource/747/07/

Boullata, I. J. (1980). Critical perspectives on modern Arabic literature. Washington: Three .Continents Press.

Celi, I. A. (2008). Alternative history, expanding identity: Myths reconsidered in Mahmoud .Darwish’s poetry. In H.. K. Najat Rahman (Ed.), Mahmoud Darwish: Exile’s poet: Critical essays (pp. 273-291). Massachusetts: Olive Branch.

Darwish, M. (1980). A letter from the Exile. Mahmud Darwish and Ben Bennani. Boundary 2. 8(3), 203-206. Retrieved from http://www.jstor.org/stable/302984?seq=1\#page_scan_tab_contents

Darwish, M. (1986). Sand and other poems. (R. Kabbani, Trans.). London: K. P. I.

Darwish, M. (1997). Cactus forever. Al-Jadid: A Review and Record of Arab Culture and Arts, 3(14). (N. Andary, Trans.). Retrieved from http://www.aljadid.com/content/ cactus-forever

Darwish, M. (2009). Almond blossoms and beyond. (M. Shaheen, Trans.). Northampton: .Interlink Books.

Darwish, M. (2016). For my mother. (T. Fayeq Oweis, Trans.). Retrieved from http://arabicpoems.webs.com/ mahmouddarwishspoems1.htm

Dhillon, B. (2010). Subaltern voices and perspectives: The poetry of Mahmoud Darwish. Illumine: Centre for Studies in Religion and Society, 9(1), 45-65.

Hadidi, S. (2008). Mahmoud Darwish’s love poem: History, exile, and the epic call. In H. Khamis and N. Rahman (Eds.), Mahmoud Darwish: Exile’s poet: Critical essays (pp. 95-122). Massachusetts: Olive Branch.

Harlow, B. (1987). Resistance literature. New York: Methuen.

Hijjawi, S. (1968). Poetry of resistance in occupied Palestine. Baghdad: The Ministry of .Culture. Retrieved from http://sulafahijjawi.ps/PoetryOfResistance_Sulafa_Hijjawi.pdf

Jabr, A. F. (2000). Innovation in Palestinian literature: Testimonies of Palestinian poets .and writers. Jerusalem: The Ogarit Centre for Publication and Translation.

Jayyusi, S. K. (2008). Forward: Mahmoud Darwish’s mission and place. In H. Khamis and N. Rahman (Eds.), Mahmoud. Darwish: Exile's Poet: Critical essays (pp. vi-xiv). Massachusetts: Olive Branch.

Loomba, A. (1998). Colonialism/ postcolonialism. London: Routledge.

Ludden, D. (2011). A brief history of subalternity. Reading Subaltern Studies. London: Anthem Press. Retrieved from http://www.sas.upenn.edu/ dludden/ReadingSS_INTRO.pdf

Nakkleh, E. A. (1980). Wells of bitterness: A survey of Israeli-Arab political poetry. In I. J. Boullata (Ed.), Critical .perspective on modern Arabic literature (pp. 244-262). Washington: Three Continents Press.

Parker, R. D. (2008). How to interpret literature: Critical theory for literary and cultural studies. New York: Oxford U. 
Raheb, M. (2016). Biblical narrative and Palestinian identity in Mahmoud Darwish's writings. Retrieved from https://www.google.jo/webhp?sourceid=chrome-instant\&ion=1\&espv=2\&ie=UTF-8\#q=Raheb\%2C+Mitri.+Biblical+Narrati ve+and+Palestinian+Identity+in+Mahmoud+Darwish\%E2\%80\%99s+Writings

Said, E. W. (1978). Orientalism. London: Penguin.

Said, E. W. (1999). After the last sky: Palestinian lives. Columbia: Columbia University Press.

Said, E. W. (2000). The Edward Said reader. (M. Bayoumi \& A. Rubin. Eds.). London: .Granta Books.

Sayegh, F. A. (1964). The Arab-Israeli conflict. New York: The Arab Information Center. 